\title{
TU/e EmonONEN

\section{Ultrafast atomic layer deposition of alumina layers for solar cell passivation}

\section{Citation for published version (APA):}

Poodt, P., Tiba, V., Werner, F., Schmidt, J., Vermeer, A. J. P. M., \& Roozeboom, F. (2011). Ultrafast atomic layer deposition of alumina layers for solar cell passivation. Journal of the Electrochemical Society, 158(9), H937-H940. https://doi.org/10.1149/1.3610994

DOI:

10.1149/1.3610994

Document status and date:

Published: 01/01/2011

\section{Document Version:}

Publisher's PDF, also known as Version of Record (includes final page, issue and volume numbers)

\section{Please check the document version of this publication:}

- A submitted manuscript is the version of the article upon submission and before peer-review. There can be important differences between the submitted version and the official published version of record. People interested in the research are advised to contact the author for the final version of the publication, or visit the $\mathrm{DOI}$ to the publisher's website.

- The final author version and the galley proof are versions of the publication after peer review.

- The final published version features the final layout of the paper including the volume, issue and page numbers.

Link to publication

\section{General rights}

Copyright and moral rights for the publications made accessible in the public portal are retained by the authors and/or other copyright owners and it is a condition of accessing publications that users recognise and abide by the legal requirements associated with these rights.

- Users may download and print one copy of any publication from the public portal for the purpose of private study or research.

- You may not further distribute the material or use it for any profit-making activity or commercial gain

- You may freely distribute the URL identifying the publication in the public portal.

If the publication is distributed under the terms of Article 25fa of the Dutch Copyright Act, indicated by the "Taverne" license above, please follow below link for the End User Agreement:

www.tue.nl/taverne

Take down policy

If you believe that this document breaches copyright please contact us at:

openaccess@tue.nl

providing details and we will investigate your claim. 


\title{
Ultrafast Atomic Layer Deposition of Alumina Layers for Solar Cell Passivation
}

\author{
P. Poodt, ${ }^{\text {a,z }}$ V. Tiba, ${ }^{\text {a }}$ F. Werner, ${ }^{\text {b J. Schmidt, }}{ }^{\text {b }}$ A. Vermeer, ${ }^{\text {c }}$ and F. Roozeboom ${ }^{\text {a,d, }}$, \\ ${ }^{a}$ TNO, 5600 HE Eindhoven, The Netherlands \\ ${ }^{b}$ Institute for Solar Energy Research Hamelin, D-31860 Emmerthal, Germany \\ ${ }^{c}$ SoLayTec, 5652 AM Eindhoven, The Netherlands \\ ${ }^{d}$ Department of Applied Physics, Eindhoven University of Technology, 5600 MB Eindhoven, The Netherlands
}

\begin{abstract}
An ultrafast atomic layer deposition technique is presented, based on the spatial separation of the half-reactions, by which alumina layers can be deposited with deposition rates of more than $1 \mathrm{~nm} / \mathrm{s}$. The deposition rate is limited by the water half-reaction, for which a kinetic model has been developed. The alumina layers showed excellent passivation of silicon wafers for solar cell applications. Based on this concept, a high-throughput ALD deposition tool is being developed targeting throughput numbers of up to $3000 \mathrm{wafers} / \mathrm{h}$.

(C) 2011 The Electrochemical Society. [DOI: 10.1149/1.3610994] All rights reserved.
\end{abstract}

Manuscript submitted January 6, 2011; revised manuscript received June 22, 2011. Published July 20, 2011. This was Paper 1438 presented at the Las Vegas, Nevada, Meeting of the Society, October 10-15, 2010.

Atomic Layer Deposition (ALD) is a deposition technique capable of producing ultrathin conformal films with superior control of the thickness and composition of the films at the atomic level. ${ }^{1}$ In conventional ALD, the deposition reaction is divided in two timesequenced self-limiting half-reactions, each one being separated by purge steps. In the case of $\mathrm{Al}_{2} \mathrm{O}_{3}$, one deposition cycle includes a dose of an aluminum precursor (mostly trimethyl aluminum, TMA), followed by a purge step to remove excess precursor and reactants, a subsequent oxidation step by dosing $\mathrm{H}_{2} \mathrm{O}, \mathrm{O}_{2}$ or $\mathrm{O}_{3}$ and, finally, another purge step. Conventional thermal ALD usually takes place at elevated temperatures and at low reactor pressure. One or more cycle steps may also be facilitated by e.g. a plasma (Plasma Enhanced ALD). ${ }^{2}$ The layer growth during such a cycle, or Growth Per Cycle (GPC), is typically $\sim 0.1 \mathrm{~nm} /$ cycle. $^{3}$ Thus to obtain thicker films, the cycles have to be repeated many times. As each cycle step can take up to several seconds, the overall deposition rates are of the order of a few nanometers per minute. One way to speed up the process is by batch processing, ${ }^{4}$ but this is not always compatible with industrial needs.

Recently, we presented an ALD concept based on the spatial separation of the half-reactions, rather than temporal, combined with gasbearing technology. ${ }^{5,6}$ In this concept, illustrated schematically in Fig. $1 \mathrm{a}$, the reactor is divided in separate zones exposing the precursors one by one to a substrate that moves underneath the reactor. Between and around the reaction zones, shields of inert gas separate the precursor flows. When operated properly, these gas shields can act as gas bearings, facilitating virtually frictionless movement between reactor and substrate. Furthermore, the gas bearings act as excellent diffusion barriers between the reaction zones, preventing cross-reactions and parasitic deposition on the reactor walls. Most importantly, the combination of the fast half-reactions and the redundancy of purge steps allows for very high deposition rates, while maintaining the typical ALD assets like film quality and conformality.

An obvious application for spatial ALD is backside passivation of crystalline silicon solar cells. Silicon solar cell efficiency can be increased by applying thin $\mathrm{Al}_{2} \mathrm{O}_{3}$ films by ALD for surface passivation. ${ }^{8-10}$ Such films combine excellent chemical passivation with field effect passivation caused by a high intrinsic negative charge density fixed at the $\mathrm{Si}-\mathrm{Al}_{2} \mathrm{O}_{3}$ interface. This implies a breakthrough in the production of high-efficiency solar cells, but also opens the way to using thinner silicon wafers, where surface passivation is of utmost importance. Here, the requirement called for is the availability of an ALD deposition technique meeting the industrial throughput requirements of $\sim 3000$ wafers/hr. This comes within reach when using spatial ALD.

\footnotetext{
* Electrochemical Society Active Member.

${ }^{\mathrm{z} E-m a i l: p a u l . p o o d t @ t n o . n l ~}$
}

Spatial ALD as an enabling technology for cost-effective passivation of crystalline silicon solar cells has been reported earlier by us ${ }^{11,12}$ and others. ${ }^{13}$ In this paper, we further examine the possibilities of spatial ALD regarding industrialization.

\section{Experimental}

A proof-of-principle reactor was constructed, where the separate reaction zones' inlets are incorporated in a round reactor head, surrounded and separated by gas bearing planes (Fig. 1b). The reactor head is mounted on top of a rotating substrate table holding the substrate as illustrated in Fig. 1c. The experimental parameters are listed in Table I and described in more detail in Ref. 6. Trimethyl aluminum (TMA) and water are used as reactants. All depositions were performed at $200^{\circ} \mathrm{C}$ at atmospheric pressure.

\section{Results}

With the experimental set-up, a $3 \mathrm{~cm}$ wide ring-shaped track of $\mathrm{Al}_{2} \mathrm{O}_{3}$ was deposited, corresponding to the width and position of the deposition inlets (Fig. 2). The color of the layer is caused by interference effects, where the blue color corresponds to a thickness of $\sim 100 \mathrm{~nm}$. Layers with thicknesses of up to $500 \mathrm{~nm}$ were deposited, showing an excellent linear relation between the layer thickness and the total number of rotations. The concept was tested successfully up to a rotational frequency of $600 \mathrm{rpm}$. Higher frequencies could not be tested due to mechanical limits of the set-up. With a growth per cycle around $0.1 \mathrm{~nm} /$ cycle, this results in deposition rates in the order of $60 \mathrm{~nm} / \mathrm{min}$. The layer thickness is homogeneous along the width of the deposition track for all rotational frequencies $(\sim 5 \%$ inhomogeneity can be achieved). This is proof of having a true ALD deposition regime with little or no CVD component. Prolonged experimental runs showed no accumulated parasitic deposition, thus indicating sufficient separation of the precursor by the gas bearing.

Next, the GPC as a function of rotation frequency was measured, while keeping the deposition temperature, gas- and precursor flows constant (Fig. 3). The GPC decreases slightly with increasing rotation frequency, from $\sim 0.13 \mathrm{~nm} /$ cycle at $60 \mathrm{rpm}$ to $\sim 0.10 \mathrm{~nm} /$ cycle at $600 \mathrm{rpm}$. The shorter precursor exposure times at higher frequencies lead to an incomplete saturation of the substrate. By increasing the precursor partial pressure it should be possible to increase the level of saturation. The standard TMA partial pressure being $\sim 1$ mbar, neither a 2.5 times higher TMA partial pressure $(\sim 2.5 \mathrm{mbar})$, nor half the TMA partial pressure $(\sim 0.5$ mbar $)$ showed any effect on the GPC at frequencies of $600 \mathrm{rpm}$. In contrast, the water partial pressure (standard value $\sim 124$ mbar) has a significant effect on the saturation behavior, and thus the GPC. (Fig. 3), with a GPC of 0.095 $\mathrm{nm} /$ cycle at half the standard water partial pressure $(\sim 62 \mathrm{mbar})$ and $0.11 \mathrm{~nm} /$ cycle at a $\sim 3$ times higher water partial pressure 


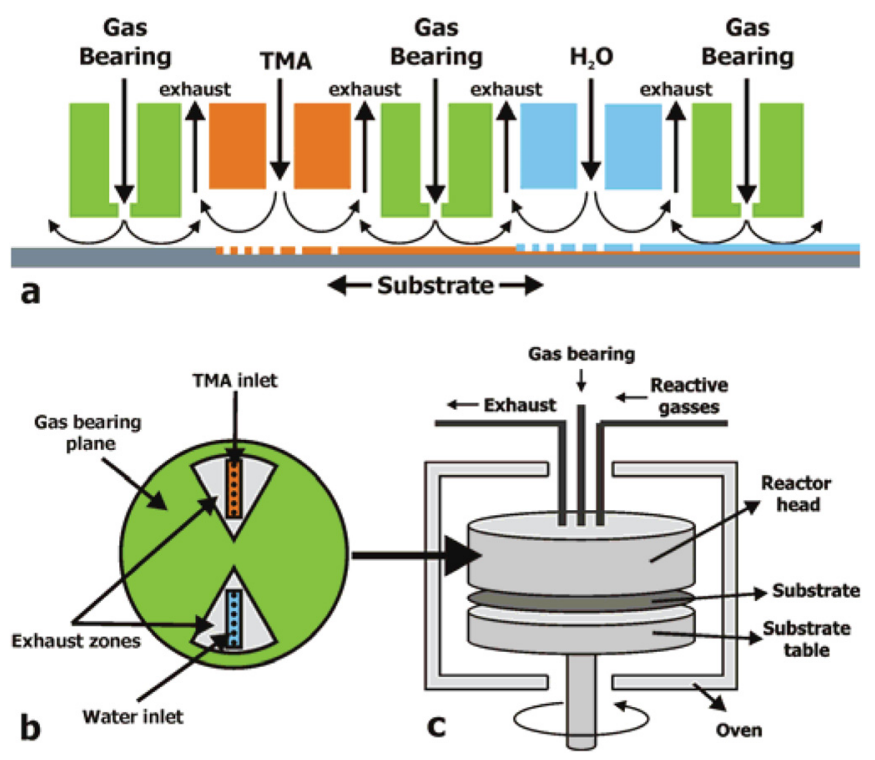

Figure 1. (Color online) (a) Schematic drawing of the spatial ALD reactor concept, where the TMA and water half-reaction zones are separated by gas bearings. By moving the substrate underneath the reactor, the two half-reactions will take place sequentially to form an $\mathrm{Al}_{2} \mathrm{O}_{3}$ monolayer. (b) Schematic drawing of the bottom side of the spatial ALD reactor head, where the TMA and water half-reaction zones are integrated into inlets surrounded by exhaust zones and gas bearing planes. (c) Schematic drawing of the reactor. The reactor head and rotating substrate table with the substrate in between are placed in a convection oven. The substrate table is rotated by a servo motor, connected by a drive shaft. The process- and waste gas lines are connected to the reactor head through an opening in the top of the oven.

( $\sim 340$ mbar). It can thus be concluded that the water half-reaction is the rate limiting step in the ALD reaction.

A kinetic model has been developed to describe the spatial ALD reaction between TMA and water. As the water half-reaction is rate limiting, modeling this step would give a sufficient description of the spatial ALD process.

Kinetic model.-After each TMA dose, and before the water dose, the surface is covered by the unreacted methyl groups of the adsorbed TMA species and remaining unreacted hydroxyl groups. The growth per cycle is determined by the half-reaction between the methyl groups of the TMA molecules at the interface and the incoming water molecules as given by

$$
\vdash \mathrm{CH}_{3}+\mathrm{H}_{2} \mathrm{O} \rightarrow \vdash \mathrm{OH}+\mathrm{CH}_{4}
$$

with $\vdash \mathrm{CH}_{3}$ and $\vdash \mathrm{OH}$ being the methyl and hydroxyl groups adsorbed at the $\mathrm{Al}_{2} \mathrm{O}_{3}$ interface. Such a reaction can be described by Eley-Rideal kinetics. ${ }^{14}$ The rate equation is then given by

$$
\frac{\partial\left[\mathrm{CH}_{3}\right]}{\partial t}=-k\left[\mathrm{CH}_{3}\right]\left[\mathrm{H}_{2} \mathrm{O}\right] \text { or } \frac{\partial N_{M e}(t)}{\partial t}=-k N_{M e}(t) p_{w}
$$

where $N_{M e}(t)$ is the time-varying methyl group concentration, $k$ is the rate constant and $p_{w}$ is the water partial pressure. It is assumed

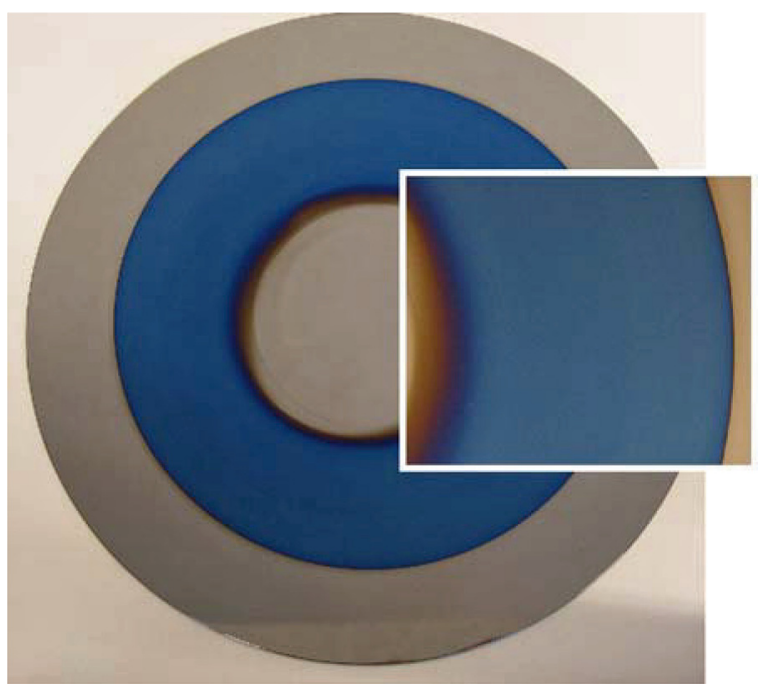

Figure 2. (Color online) Photograph of a $150-\mathrm{mm}$ silicon wafer with a $3 \mathrm{~cm}$ wide track of $100 \mathrm{~nm} \mathrm{Al} \mathrm{O}_{3}$ deposited by spatial ALD. The insert shows a magnification of the deposited film, where uniformity of the color indicates thickness uniformity.

that there is a high water refresh rate and the water partial pressure can be considered constant, i.e. $\frac{\partial p_{w}}{\partial t}=0$. Solving Eq. 2 gives

$$
N_{M e}(t)=N_{M e}^{0} \exp \left[-k p_{w} t\right]
$$

with $N_{M e}^{0}$ the initial methyl group concentration. The number of newly formed hydroxyl groups $N_{O H}(t)$ formed in reaction 1 is given by

$$
\frac{\partial N_{O H}(t)}{\partial t}=-\frac{\partial N_{M e}(t)}{\partial t}
$$

Combining 3 and 4 gives

$$
N_{O H}(t)=N_{O H}^{0}+N_{M e}^{0}\left(1-\exp \left[-k p_{w} t\right]\right)
$$

assuming that $\lim _{t \rightarrow 0} N_{O H}(t)=N_{O H}^{0}$ and $\lim _{t \rightarrow \infty} N_{O H}(t)=N_{O H}^{0}+N_{M e}^{0}$.

The GPC $\stackrel{t \rightarrow 0}{\text { is }}$ related to the total number of hydroxyl groups formed after the water dose plus the remaining unreacted hydroxyl groups from before the water dose

$$
G P C \propto N_{\mathrm{OH}}(t)=N_{O H}^{0}+N_{M e}^{0}\left(1-\exp \left[-k p_{w} t\right]\right)
$$

or, in a more general form

$$
G P C=A-B \exp \left[-k p_{w} t\right]
$$

with $A, B$, and $k$ as fit parameters.

Figure 4 shows the GPC versus $p_{w} t$ (or $p_{w}$ (in mbar) divided by the rotation frequency $(\mathrm{rpm})$ ), with a fit of Eq. 7. Fit parameters are: $k=1.27 \mathrm{mbar}^{-1} \mathrm{~min}^{-1}, A=0.13 \mathrm{~nm} /$ cycle and $B=0.038 \mathrm{~nm} /$ cycle. Because a relatively inaccurate bubbler system is used to evaporate the water, there is a rather large uncertainty in the water partial

Table I. Experimental parameters proof-of-principle reactor

$\mathrm{T}_{\text {deposition }}$

Total flow TMA injector

Total flow $\mathrm{H}_{2} \mathrm{O}$ injector

Gas bearing pressure

Gap substrate-gas bearing gap

Gap substrate-TMA/ $\mathrm{H}_{2} \mathrm{O}$ injector $50-350^{\circ} \mathrm{C}$

$1 \mathrm{sim}$

$1 \mathrm{slm}$

5 bar

$20 \mu \mathrm{m}$

$100 \mu \mathrm{m}$
Rotation frequency

TMA partial pressure

$\mathrm{H}_{2} \mathrm{O}$ partial pressure

Total pressure

Reactor diameter

Deposition track width
Max. $600 \mathrm{rpm}$

1-5 mbar

50-350 mbar

Atmospheric

$15 \mathrm{~cm}$

$3 \mathrm{~cm}$ 


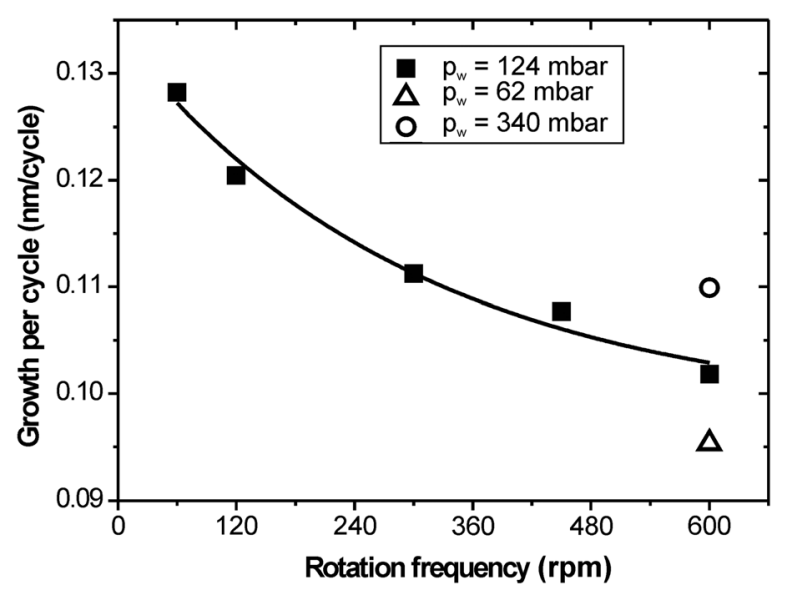

Figure 3. The growth per cycle measured as a function of rotation frequency with a water vapor pressure $\left(p_{w}\right)$ of $124 \mathrm{mbar}(\mathbf{\square}), 62 \mathrm{mbar}(\bigcirc)$ and 340 $\operatorname{mbar}(\Delta)$.

pressure. Nevertheless, the model gives an adequate description of the experimental data. From the fit to the data, a maximum obtainable rotation frequency can be estimated. Note, that from the fit a maximum GPC of $0.13 \mathrm{~nm} /$ cycle can be obtained at high $p_{w} . t$ values, so at very low rotation frequencies and very high water vapor pressures.

A typical value of $p_{w} t$ is 1 , corresponding to a GPC of $0.12 \mathrm{~nm} /$ cycle. In principle the maximum possible water vapor pressure is 1000 mbar (steam). As such, the maximum rotation frequency that can be used is $1000 \mathrm{rpm}$. This would result in a theoretical maximum deposition rate of $2 \mathrm{~nm} / \mathrm{s}$. Higher deposition rates are possible when undersaturated half-reactions are allowed. However, this might also influence the quality of the deposited films.

Using high partial pressures and high rotation frequencies might be challenging from a practical point of view. A more straightforward approach to achieve high deposition rates is to use more precursors injectors in-line, to obtain more than one cycle per rotation.

\section{Spatial ALD for surface passivation of Si solar cells}

The level of surface passivation is quantified by the effective surface recombination velocity. Assuming an infinite bulk lifetime, the upper limit of the effective surface recombination velocity $S_{\text {eff }}$ can be calculated by

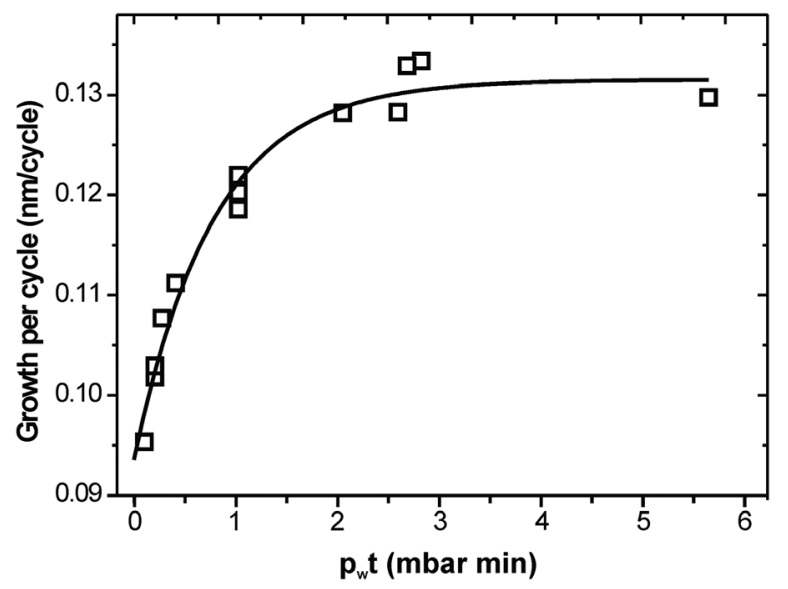

Figure 4. The growth per cycle measured as a function of $p_{w} t$ (the water partial pressure divided by the rotation frequency). The data are fitted according to Eq. 7, with $A=0.13 \mathrm{~nm} /$ cycle, $B=0.0938 \mathrm{~nm} /$ cycle and $k=1.72 \mathrm{mbar}^{-1}$ $\min ^{-1}$.

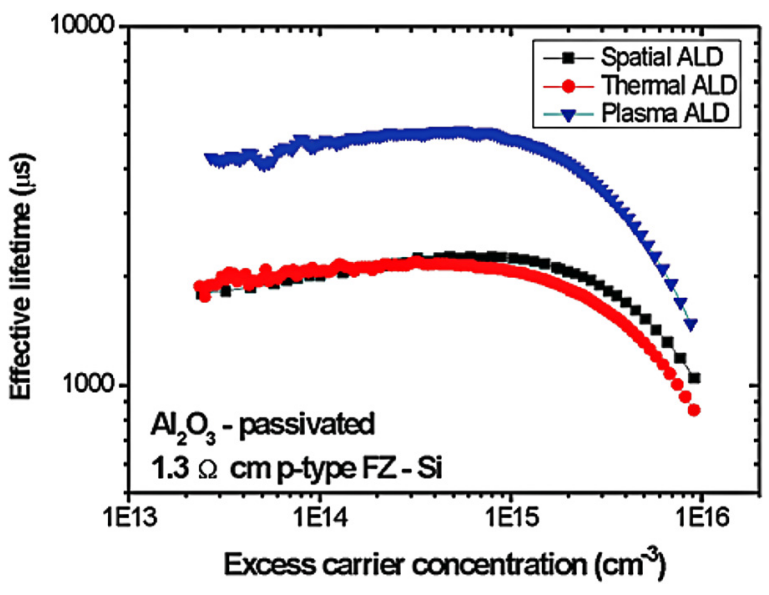

Figure 5. (Color online) Effective lifetimes and effective surface recombination velocities for Si-wafers with $\mathrm{Al}_{2} \mathrm{O}_{3}$ passivation deposited by spatial ALD. (a) $30 \mathrm{~nm} \mathrm{Al}_{2} \mathrm{O}_{3}$ on a $180 \mu \mathrm{m}$ n-type FZ Si wafer $(2-3 \Omega \cdot \mathrm{cm})$ and (b) $10 \mathrm{~nm} \mathrm{Al}_{2} \mathrm{O}_{3}$ deposited on a $130 \mu \mathrm{m}$ p-type CZ Si wafer $(1-3 \Omega \cdot \mathrm{cm}$, bulk lifetime 300-500 $\mu \mathrm{s}$ ).

$$
S_{\text {eff }} \leq \frac{d}{2 \tau_{\text {eff }}}
$$

with $d$ the substrate thickness and $\tau_{\text {eff }}$ the effective lifetime. Figure 5 shows the effective lifetimes $\tau_{\text {eff }}$ measured as a function of the injection density $\Delta n$ for $1.3 \Omega \cdot \mathrm{cm} p$-type float-zone silicon (FZ-Si) wafers passivated using $\mathrm{Al}_{2} \mathrm{O}_{3}$ deposited by plasma-assisted, thermal and spatial ALD (deposition temperature $200^{\circ} \mathrm{C}$, rotation frequency 120 $\mathrm{rpm})$. Lifetimes were measured by the photoconductance decay (PCD) method using a Sinton lifetime tester. $\mathrm{All}_{2} \mathrm{Al}_{2} \mathrm{O}_{3}$ films received a post-deposition anneal at $(400 \pm 50)^{\circ} \mathrm{C}$ for $\sim 15 \mathrm{~min}$ to activate the surface passivation. ${ }^{15}$ As can be seen from Fig. 5, all three ALD techniques result in $\mathrm{Al}_{2} \mathrm{O}_{3}$ films of outstanding surface passivation quality, which shows an extremely weak injection dependence over the complete relevant injection range between $10^{13}$ and $10^{15} \mathrm{~cm}^{-3}$. Most importantly, it can be deduced from Fig. 5 that both traditional thermal ALD as well as spatial ALD provide $\mathrm{Al}_{2} \mathrm{O}_{3}$ films with an extremely high level of surface passivation, as indicated by lifetimes of $2 \mathrm{~ms}$, corresponding to an upper surface recombination velocity (SRV) limit of $S_{\text {eff }}<7 \mathrm{~cm} / \mathrm{s}$, for both techniques and a practically negligible injection dependence over the relevant injection range. Furthermore, excellent firing stabilities of the alumina films have been observed. ${ }^{11,12}$ It is quite remarkable that spatial ALD with its high deposition rates produces exactly the same excellent level of surface passivation as the slow $(<2 \mathrm{~nm} / \mathrm{min})$ thermal ALD. Although further optimization is required, our preliminary results show already that $\mathrm{Al}_{2} \mathrm{O}_{3}$ deposited by spatial ALD combines excellent surface passivation with high deposition rates.

It goes without saying that surface passivation of square silicon solar cell wafers requires uniform deposition of $\mathrm{Al}_{2} \mathrm{O}_{3}$ over the entire wafer area, rather than a circular track. Thus a rotary spatial ALD reactor cannot be used. For this reason, a reciprocating spatial ALD tool has been developed capable of processing full wafers at high throughput numbers (Fig. 6). Inside this tool, substrates are moved back and forth all the way underneath a spatial ALD injector with the same width as the substrate. ${ }^{16}$ By using a double gas bearing (below and above the substrate, Fig. 6a), the substrate will float virtually frictionless underneath the injector zones. By pulsing flows of inert gas in the substrate drives next to the injector (Fig. 6b), the wafer can be moved back and forth without utilizing carriers. The wafers are centered by flows of gas perpendicular to the movement direction, on both sides of the wafer (Fig. 6b). When a deposition is finished, the substrate will be transported away from the injector head and a new substrate comes in immediately. A significant benefit of using a single injector with a reciprocating wafer is that the 


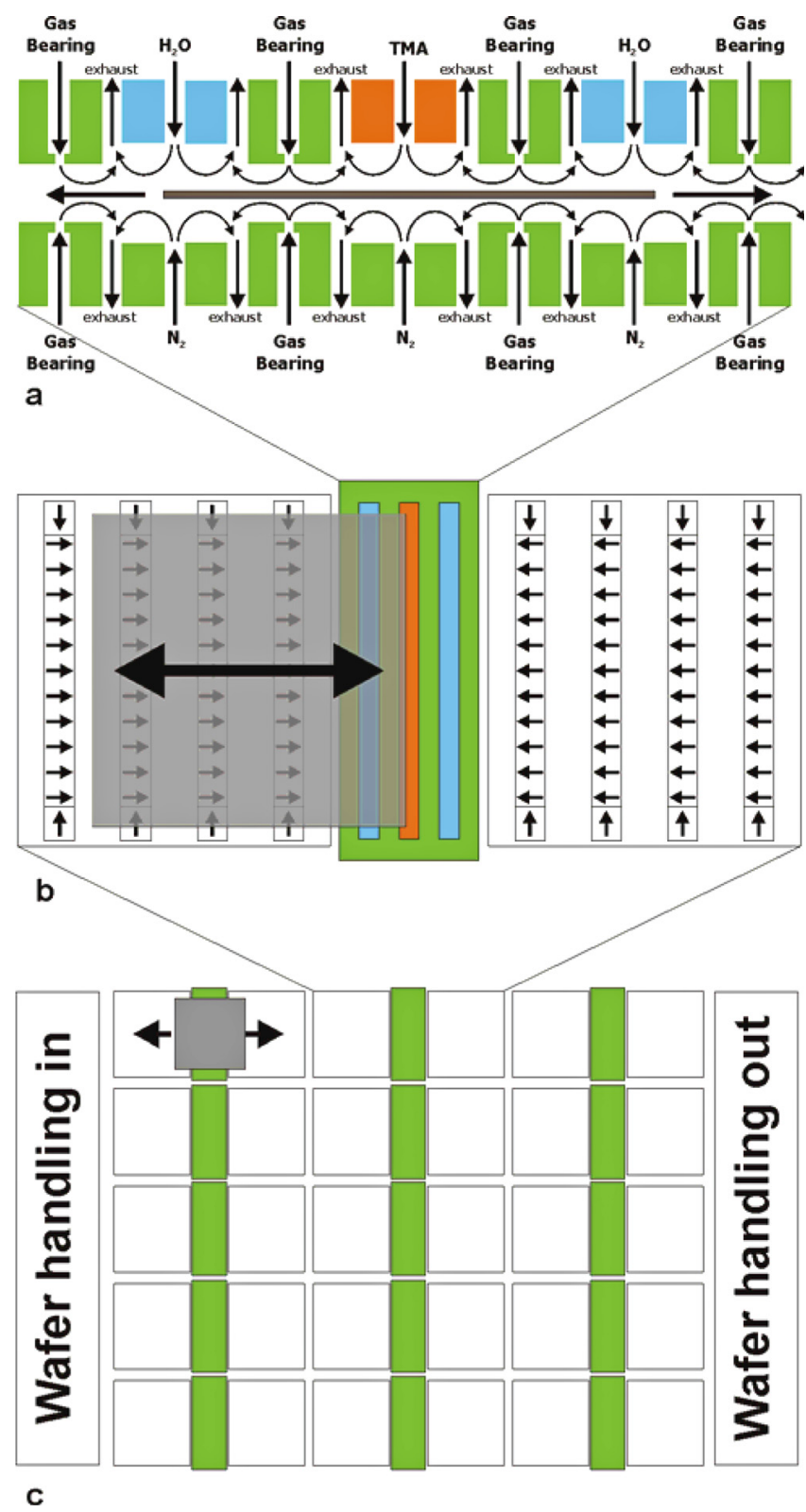

Figure 6. (Color online) (a) Schematic drawing of the double floating spatial ALD reactor, in which $156 \times 156 \mathrm{~mm}$ wafers are transported back and forth, in a reciprocating motion underneath a spatial ALD injector head with the same width as the wafer. Thus the wafers are carried and moved by flows and pulses of inert gas without using wafer carriers. (b) The injector head is surrounded by wafer drives that supply the reciprocal motion of the wafer by pulses of inert gas. (c) To achieve industrial throughput numbers, several of these units can be placed in parallel and modular use.

film thickness is tuned by simply selecting the number of passages of the substrate.

Also here, the gas bearing gaps on both sides of the floating wafer should be very small to prevent cross-reactions between the precursors. Typically, a gap in the range of 3-15 $\mu \mathrm{m}$ between the substrate and the gas bearing (above and below) is sufficient to ensure separation between the precursors. However, the gaps should be large enough to account for the thickness variations of the substrates. The gap in the TMA- and water half-reaction zones can be larger than the bearing gap, typically up to $100 \mu \mathrm{m}$.
The total deposition rate depends on the number of TMA and water slots that are integrated in the injector head, in combination with the number of passages of the substrate per second. Currently, each substrate passes 4 times per second through the injector head containing a single TMA slot, resulting in an effective deposition rate of $\sim 0.4 \mathrm{~nm} / \mathrm{s}$. This allows for throughput numbers of the order of 100 wafers $/ \mathrm{h}$, based on a passivation layer thickness of $10 \mathrm{~nm}$. However, it is possible to integrate two or three TMA and water half-reaction zones, thus increasing the throughput accordingly. With this tool, homogeneous deposits ( $2-4 \%$ thickness variation) with low effective recombination velocities are obtained over the entire area of the wafer, with minimal backside deposition $(\sim 30$ $\mathrm{cm} / \mathrm{s}$ for $180 \mu \mathrm{m} p$-type CZ wafers, $1-5 \Omega \mathrm{cm}$, but highly dependant on type, quality, pre- and post-treatment of the Si wafer).

Further upscaling to industrial scale can be achieved by incorporating 10 or up to 15 injectors in parallel use, as a modular system (Fig. 6c). In this way throughputs of more then 3000 wafers/h can be obtained while keeping a relatively small footprint.

\section{Conclusions}

We have demonstrated that by spatially separated ALD in combination with gas bearing technology, high-quality $\mathrm{Al}_{2} \mathrm{O}_{3}$ layers can be deposited at deposition rates of at least $1.2 \mathrm{~nm} / \mathrm{s}$. With these films, very low effective surface recombination velocities were obtained, showing excellent surface passivation. This disruptive and high-throughput method has great potential in many other largescale applications. Other materials than $\mathrm{Al}_{2} \mathrm{O}_{3}$ will further expand this potential. Currently, an in-line industrial spatial ALD tool for passivating square silicon solar cells is being developed, aiming at throughput numbers of 3000 wafers/h as a lead to cost-effective, next generation production tools.

\section{Acknowledgments}

The authors would like to thank J. Smeltink and S. Broers for reactor design, construction and technical assistance. The project supervision by A. van Asten en R. Görtzen and the co-inventorship by K. Spee, D. Maas, B. van Someren, A. Lexmond and A. Duisterwinkel are gratefully acknowledged.

\section{References}

1. S. George, Chem. Rev., 110, 111 (2010), and references therein.

2. W. M. M. Kessels, H. B. Profijt, S. E. Potts and M. C. M van de Sanden, in ALD of Nanostructured Materials, M. Knez and N. Pinna, Editors, VCH-Wiley, Weinheim (2011).

3. R. L. Puurunen, J. Appl. Phys., 97, 121301 (2005).

4. E. Granneman, P. Fischer, D. Pierreux, H. Terhorst, and P. Zagwijn, Surf. Coat. Technol. 201, 8899 (2007).

5. D. J. Maas, B. van Someren, A. S. Lexmond, C. I. M. A. Spee, A. E. Duisterwinkel, and A. J. P. M. Vermeer, European Pat. 2159304 (A1) (2010) and WO Pat. 2010/024671 (2010)

6. P. Poodt, A. Lankhorst, F. Roozeboom, K. Spee, D. Maas, and A. Vermeer, Adv. Mater. 22, 3564 (2010).

7. D. H. Levy, S. F. Nelson, and D. Freeman, J. Display Technol., 5, 484 (2009).

8. J. Schmidt, A. Merkle, R. Brendel, B. Hoex, M. C. M. van de Sanden, and W. M. M. Kessels, Prog. Photovoltaics, 16, 461 (2008).

9. J. Benick, B. Hoex, M. C. M. van de Sanden, W. M. M. Kessels, O. Schultz, and S W. Glunz, Appl. Phys. Lett., 92, 253504 (2008)

10. W. C. Sinke, W. van Hooff, G. Coletti, B. Ehlen, G. Hahn, S. Reber, J. John, G. Beaucarne, E. van Kerschaver, M. de Wild-Scholten, and A. Metz, Proceedings of 24th EU-PVSEC, Hamburg, p. 845 (2009).

11. F. Werner, B. Veith, V. Tiba, P. Poodt, F. Roozeboom, R. Brendel, and J. Schmidt, Appl. Phys. Lett., 97162103 (2010).

12. B. Vermang, A. Rothschild, A. Racz, J. John, J. Poortmans, R. Mertens, P. Poodt V. Tiba, F. Roozeboom, Prog. Photovoltaics, accepted.

13. V. Kuznetsov E. H. A. Granneman, P. Vermont, and K. Vanormelingen, ECS Trans. 33(2) 441 (2010).

14. D. D. Eley and E. K. Rideal, Proc. R. Soc. London, Ser. A, 178452 (1941).

15. J. Schmidt, B. Veith, F. Werner, D. Zielke, and R. Brendel, in Proceedings of 35th IEEE PVSC, Honolulu, HI, p. 885 (2010).

16. A. Vermeer and G. Janssen, WO Pat. 2011/014070 (2011) 